\title{
EFFECT OF COLOUR OF LIGHT ON THE OPENING OF INFLORESCENCE BUDS AND POST-HARVEST LONGEVITY OF POT CHRYSANTHEMUMS (Chrysanthemum $x$ grandiflorum (Ramat.) Kitam)
}

\author{
Marek Jerzy, Piotr Zakrzewski, Anita Schroeter-Zakrzewska \\ Poznań University of Life Sciences, Department of Ornamental Plants, Dąbrowskiego 159, 60-594 Poznań, Poland \\ e-mail: anitazak@up.poznan.pl
}

Received: 20.02.2011

\begin{abstract}
The pot cultivar of Chrysanthemum x grandiflorum 'Leticia Time Yellow' was cultivated and stored in a growth room under fluorescent light of white, blue, green, yellow and red colour. Quantum irradiance was $30 \mu \mathrm{mol} \cdot \mathrm{m}^{-2} \times \mathrm{s}^{-1}$. The colour of light exerted a significant influence on the opening of closed inflorescence buds and on post-harvest longevity of pot chrysanthemums grown earlier in an unheated plastic tunnel. Under florescent lamps emitting blue light at a wavelength of 400-580 nm, inflorescence buds opened and coloured the earliest. The number of developed flower heads was the greatest under blue and white light. Flower heads developing in blue light were bigger than flower heads developing in white and green light. In red light at a wavelength of 600-700 nm, plants flowered latest and they produced the smallest flower heads. Post-harvest longevity was preserved longest in chrysanthemums kept under blue, white and green light. In red and yellow light, the flowers were overblown earliest.
\end{abstract}

Key words: Chrysanthemum x grandiflorum, artificial lighting, post-harvest life, pot plants

\section{INTRODUCTION}

Light is one of the most important environmental factors exerting an effect on plant development. B orowski and Kozłowska (1986), who studied the effect of light colour on the growth of mother plants and rooted cuttings of 'Horim Golden' chrysanthemums, found that mother plants grew best in red light and also the cuttings became rooted the quickest in the red colour. Also the white colour has a beneficial effect, but the blue light and particularly the green one have a negative influence on mother plants and on the rooting of cuttings.

In red light, the plant stems become longer, contributing thereby to an increased flabbiness of shoots
(Moe and Heins, 1990; Khattak and Pears o n, 1997).

The effect of the colour of light on the growth and development of chrysanthemums has been an object of research by many authors for more than ten years. Especially worth noting are studies investigating the possibility of growing chrysanthemums under filters with $\mathrm{CuSO}_{4}(\mathrm{Mc}$ Mahon et al. 1991; R a japakse and Kelly, 1992, 1995; Mc Mahon and Kelly, 1995, 1999) or under photoselective film (O y a e rt et al. 1999; Li et al. 2000). Light of blue colour retards the growth of chrysanthemums to a lesser or greater extent and accelerates their flowering significantly ( $\mathrm{Z}$ a le w s k a et al. 2002; S h i mizu et al. 2006). Maki et al. (2002), and King (2006) found that in light with a low proportion of red in relation to far red, chrysanthemum showed higher gibberellin content and the stems elongated greatly. In the reversed conditions, elongation is stopped, the plants are more compact and start to branch (R ajapakse et al. 1993; K h a t ta k et al. 2004).

The effect of the colour of light on the development of closed inflorescence buds and postharvest longevity of pot chrysanthemums has not been studied yet. It now appears that light with a specified wavelength has a significant influence on both flowering and senescence of chrysanthemum flower heads chrysanthemum. This has been the finding of the present research.

\section{MATERIALS AND METHODS}

Small-flowered pot chrysanthemums (Chrysanthemum $x$ grandiflorum (Ramat.) Kitam) 'Leticia Time Yellow' were grown in a growth chamber under fluorescent lamps of TLD-36-W type. In 2007, experiments were carried out under lamps of three colours. 
white $33(360-700 \mathrm{~nm})$, blue $18(400-580 \mathrm{~nm})$ and green 17 (360-630 nm). In 2008, another experiment was performed using the same colours of lamps and also two kinds of lamps emitting yellow $16(500-650 \mathrm{~nm})$ and red 15 (600-700 nm) colours of light. In order to equalize the irradiance quantum, two white lamps and two blue lamps were hung $54 \mathrm{~cm}$ above the plants; two green lamps were hung $52 \mathrm{~cm}$ above the plants; three yellow lamps were placed $46 \mathrm{~cm}$ above the plants and 8 red lamps were fixed at the height of $27 \mathrm{~cm}$ above the plants. Irradiance was $655 \mathrm{~mW} \times \mathrm{m}^{-2}$; quantum irradiance (PPFD) was $30 \mu \mathrm{mol} \times \mathrm{m}^{-2} \mathrm{~s}^{-1}$ respectively. On shelves in the growth chamber, 10 pots of $14 \mathrm{~cm}$ diameter, with 5 plants in each pot, were placed on each shelf (earlier, the plants had been grown in an unheated plastic tunnel). Air temperature in the growth chamber was maintained at a constant level of $17 \pm 1^{\circ} \mathrm{C}$ and air humidity was $65-70 \%$. Day length lasted 10 hours (8:00 - 18:00).

Spectral characteristics of the fluorescent lamps of Philips TLD type determined with the use of a spectroradiometer (USB 4000) are shown in Figure 1.

Experiment I, concerning the development of inflorescence buds, was carried out in the spring period, from May 23 to June 15, 2007 and in autumn from Sept. 12 to October 14, 2008. The experiment was started at the stage of microscopic development of inflorescence buds, on the day when the buds were still green and closed, but they were ready to change colour and to continue their further development. Then, the duration of colouration in the inflorescence buds and the time of flowering were determined. At the full bloom stage, when in one pot one half of flower heads were fully blown, the flower diameters were measured and fully blown flower heads were counted.
Experiment II, concerning the post-harvest life of flowers, was carried out in the spring-summer period of 2007 (from June 11 to July 12) and in the autumn period 2008 (from 3rd to 30th of October). Observations on post-harvest life of flowers were started at the full bloom s. After flower senescence, the post-harvest life of plants was determined by counting the number of days which had passed from the full bloom stage to the moment when the flowers lost their ornamental value, and the number of overblown heads was also counted. Conventionally, it was accepted that the ornamental value was lost on the day when one half of the apical flowers heads in the pot were overblown.

Results of measurements were statistically processed by analysis of variance using Duncan's test at the significance level of $a=0.05$.

\section{RESULTS}

In spring 2007, after the equalization of irradiance quantum of the three light colours (white, blue, green) to an equal level of $30 \mu \mathrm{mol} \times \mathrm{m}^{-2} \times \mathrm{s}^{-1}$, the development of inflorescence buds of 'Leticia Time Yellow' chrysanthemum took place at the quickest rate under the blue and white light, in 20 (blue) and 21 (white) days, respectively. The development of inflorescence buds under the green light lasted slightly longer, on the average 23 days. Flower heads developing in blue light were bigger than flower heads developing in white and green light. The number of flower heads did not depend on the colour of light (Table 1).

Post-harvest life of chrysanthemums in 2007 was high and it lasted 30-31 days. The number of overblown flower heads did not depend on the light colour (Table 2).

Table 1.

Effect of fluorescent light colour on the development of closed inflorescence buds

\begin{tabular}{|c|c|c|c|c|c|}
\hline \multirow{2}{*}{ Light } & \multicolumn{3}{|c|}{ Bud development (days) } & \multirow{2}{*}{$\begin{array}{c}\text { Number of } \\
\text { developed flower } \\
\text { heads }\end{array}$} & \multirow{2}{*}{$\begin{array}{l}\text { Flower head } \\
\text { diameter } \\
(\mathrm{cm})\end{array}$} \\
\hline & colouring & blooming & total days & & \\
\hline \multicolumn{6}{|c|}{2007} \\
\hline white & $9 \mathrm{a}$ & $12 \mathrm{~b}$ & $21 \mathrm{a}$ & $12.8 \mathrm{a}$ & $4.8 \mathrm{a}$ \\
\hline blue & $10 a b$ & $10 \mathrm{a}$ & $20 \mathrm{a}$ & $12.3 \mathrm{a}$ & $5.6 \mathrm{~b}$ \\
\hline green & $11 \mathrm{~b}$ & $12 \mathrm{~b}$ & $23 \mathrm{~b}$ & $11.7 \mathrm{a}$ & $4.8 \mathrm{a}$ \\
\hline \multicolumn{6}{|c|}{2008} \\
\hline white & $13 \mathrm{~b}$ & $16 b$ & $29 b$ & $13.2 b$ & $5.1 \mathrm{~b}$ \\
\hline blue & $10 \mathrm{a}$ & $16 b$ & $26 a$ & $13.6 b$ & $5.6 b$ \\
\hline green & $16 \mathrm{c}$ & $14 \mathrm{a}$ & $30 \mathrm{~b}$ & $10.6 a$ & $5.1 \mathrm{~b}$ \\
\hline yellow & $15 \mathrm{c}$ & $15 \mathrm{ab}$ & $30 \mathrm{~b}$ & $11.6 a$ & $4.7 \mathrm{a}$ \\
\hline red & $18 \mathrm{~d}$ & $14 \mathrm{a}$ & $32 c$ & $9.6 a$ & $4.4 \mathrm{a}$ \\
\hline
\end{tabular}



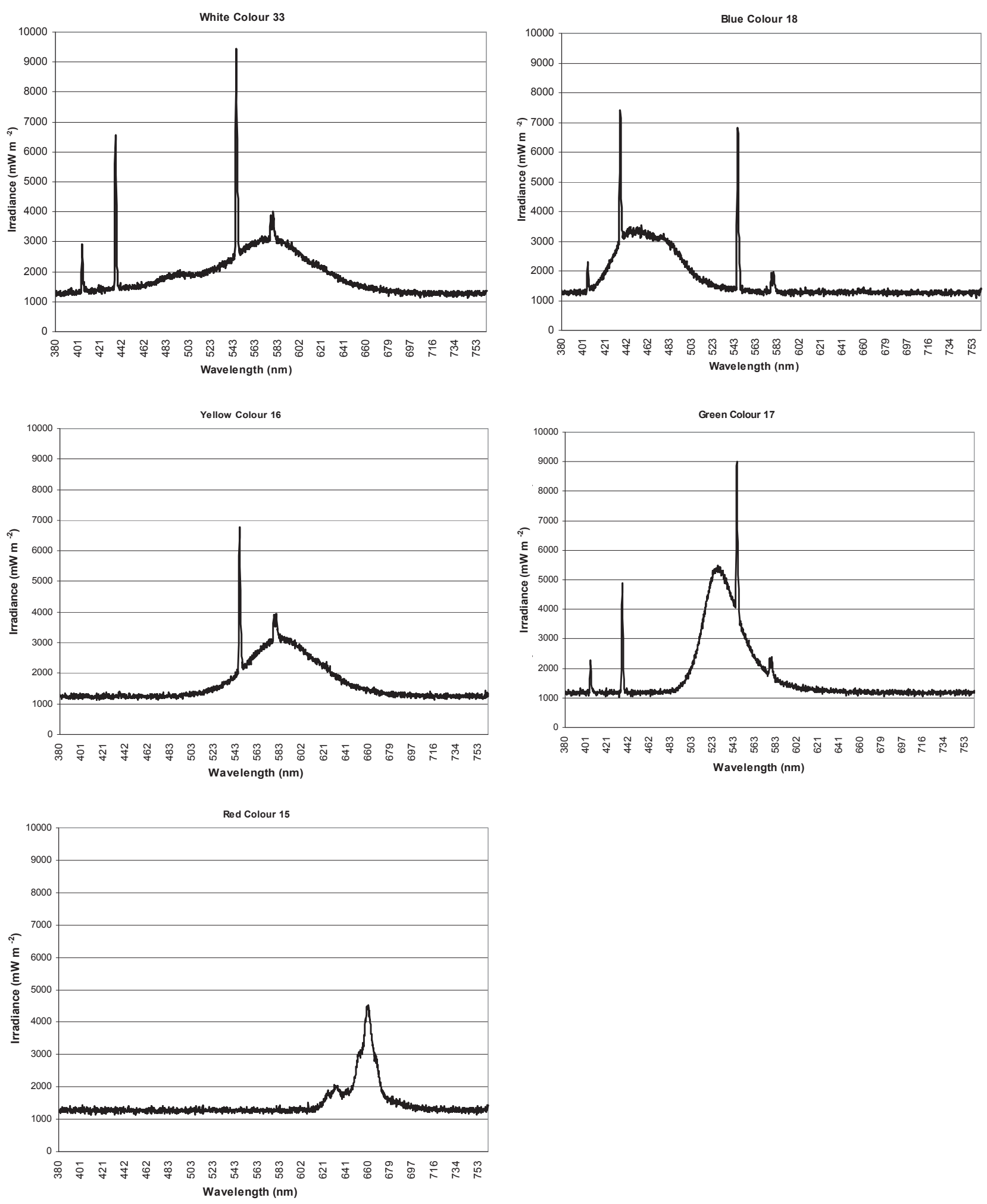

Fig. 1. Spectral characteristic of the fluorescent lamps Philips TLD $36 \mathrm{~W}$ 
Table 2.

Effect of fluorescent light colour on post-harvest longevity of chrysanthemums flowering in pots

\begin{tabular}{ccccc}
\hline \multirow{2}{*}{ Light } & \multicolumn{2}{c}{ Post-harvest longevity (days) } & \multicolumn{2}{c}{ Number of overblown apical flower heads } \\
\cline { 2 - 5 } & 2007 & 2008 & 2007 & 2008 \\
\hline white & $31 \mathrm{a}$ & $27 \mathrm{~b}$ & $11.1 \mathrm{a}$ & $7.6 \mathrm{a}$ \\
blue & $31 \mathrm{a}$ & $28 \mathrm{~b}$ & $10.7 \mathrm{a}$ & $7.3 \mathrm{a}$ \\
green & $30 \mathrm{a}$ & $26 \mathrm{~b}$ & $11.3 \mathrm{a}$ & $7.0 \mathrm{a}$ \\
yellow & - & $22 \mathrm{a}$ & - & $6.8 \mathrm{a}$ \\
red & - & $20 \mathrm{a}$ & - & $7.5 \mathrm{a}$ \\
\hline
\end{tabular}

In autumn 2008, inflorescence buds opened and coloured at the quickest rate under blue lamps (within 26 days). Under the white, green and yellow lamps, buds developed 3-4 days later. Under the red lamps, bud development lasted the longest - 32 days. Under blue, white and green light, flower heads were bigger than those developing under yellow and red light. The number of developed flower heads was the highest under blue and white light (Table 1).

In 2008 post-harvest life of the chrysanthemum cultivar Leticia Time Yellow was the longest under blue, white and green light and lasted 26-28 days, while under yellow and red light, it was shorter by 6 and 8 days, respectively. The number of apical flower heads did not depend on the colour of light (Table 2).

\section{DISCUSSION}

A lot of important information referring to the development of flower buds and to the methods of extending shelf life of cut chrysanthemum flowers can be found in the monograph by Nowak and R ud n i cki (1990). The spray cultivars designed for development should be clipped after the development of the first flower in the inflorescence, while in large-flowered cultivars it should be done when the bud diameter is about $5 \mathrm{~cm}$ long. Air temperature in the growth chamber should be $22-24^{\circ} \mathrm{C}$, relative humidity should amount to $40-80 \%$, day length - 16 hours, and light intensity should be located at the height of developing shoots - 2000 lx. At the same time, it is recommended to use fluorescence lamps for this purpose (in Poland these lamps are called „lampy jarzeniowe”). When the above conditions are met, a simultaneous addition of silver nitrate, 8-hydroxyquinoline citrate and saccharose will bring in effect a complete development of the buds of the 'Westland Brandy' cultivar within 7-9 days.

Post-harvest longevity of chrysanthemum flowers, both those grown for cutting and potted flowers, depends to a high degree on the conditions of plant growing in the period preceding harvest and storing (J e rzy, 2000). Chrysanthemums grown in good conditions are more durable. Deficit of light, particularly during the two last weeks of cultivation, has a very unfavourable effect on the quality of stored flowers. Excessive insolation also produces negative effects. Particularly the cultivars with pink, violet, red and brown flowers react negatively to such conditions. Plants grown in pots, when they are transferred to the store-room directly from the greenhouse where the light was in excess, show a better tolerance to artificial light with lower intensity than plants grown earlier under the conditions of insolation deficit.

Light and its intensity seem to be among the more important factors determining the success in the quick development of closed inflorescence buds of chrysanthemums blooming in pots. $\mathrm{Z}$ a le w s k a et al. (2002) report that the cultivar Baja from the Sombrero Group of chrysanthemums was grown under short-day conditions and exposed to artificial blue light and daylight, which constituted the control. For both colours of light, three levels of quantum irradiance were applied: 35,50 and $80 \mu \mathrm{mol} \times \mathrm{m}^{-2} \times \mathrm{s}^{-1}$. The blue light caused the plants to flower earlier than in the case of daylight. The blue light of the highest irradiance quantum slightly shortened the plant stem length.

Mc Mahon et al.(1991) observed that pot chrysanthemums of 'Spears' and 'Yellow Mandalay' cultivars developed their inflorescence buds the earliest under filters containing water solution of $\mathrm{CuSO} 4$. These filters increase in the light spectrum the values of red to far -red relation. Although the above mentioned authors regarded the buds as abnormal ones which might develop not well shaped inflorescences, they believed that during the long day photoperiod created under the filters, the vegetative phase would pass to the generative one. However, the results of later studies (McMahon and Kelly 1999), where the 'Spears' cultivar reached the flowering stage under $\mathrm{CuSO}_{4}$ filters, showed that plants growing under long day conditions bloomed 7 days later than those grown 
under short day conditions. On the other hand, when blooming of the plants was analysed in relation to the control - also in a long photoperiod - it was then found that the long day under filters with $\mathrm{CuSo} 4$ shortened the cultivation period by 10 days. No difference in flowering duration was observed between plants grown under short day conditions.

In the present experiment, it was found that the colour of light exerted an independent influence on the development of chrysanthemum inflorescence buds and on their post-harvest life. The earliest development of inflorescence buds and their colour was shown by plants under the blue lamps and also the flower heads were the largest under the blue lamps. Also post-harvest life of the plants depended on the colour of light. Plants under blue, white and green light maintained their ornamental value the longest, while plants under red and yellow light were the first to be overblown. Therefore, one can state that electromagnetic waves which are contained within the spectrum of $400-580$ $\mathrm{nm}$ have the most beneficial effect on the opening and development of inflorescence buds of 'Leticia Time Yellow' chrysanthemums. On the other hand, an unfavorable effect is exerted by electromagnetic radiation within the spectrum of 600-700 nm, which delays flower bud development and shortens the post-harvest life of the cultivar 'Leticia Time Yellow'. In our experiment, fluorescent lamps emitting blue light, which is almost completely devoid of wavelength within red and far red light colour, accelerated the flowering of chrysanthemums. The lamps emitting yellow light, which is almost completely without the blue colour range, but it is rather rich in red colour, caused a delay in flowering.

Extension of post-harvest life of chrysanthemums can have a great practical significance, for example for transport of flowers and their storage in big supermarkets and shopping centres. It is especially important to work out a method enabling to keep plants in a room without natural light, equipped with lamps with appropriately selected colour and intensity of the light.

\section{CONCLUSIONS}

Studies carried out in the growth room have indicated that light of a definite colour has a significant effect on the opening of closed inflorescence buds and on post-harvest longevity of pot chrysanthemum 'Leticia Time Yellow'.

Under blue light fluorescent lamps, inflorescence buds coloured and started blooming earliest.

In blue and white light, plants flower earliest and they produce the greatest number of flower heads, while red light had the opposite effect.
Chrysanthemums kept under lamps with blue, white and green light maintain longest their post-harvest life. In red and yellow light, the flowers were overblown earliest.

\section{REFERENCES}

Borowski E, Kozłowska L., 1986. The influence of light color on the rooting of 'Horim Golden' chrysanthemum cuttings. Acta Agrobot.39:47-57.

Jerzy M., 2000. Chrysanthemums. Cultivars and culture. Powszechne Wydawnictwo Rolnicze i Leśne Warszawa:121-124 (in Polish).

Khattak A.M., Pearson S., Johnson C.B., 2004. The effects of far red spectral filters and plant density on the growth and development on chrysanthemums. Sci. Hortic. 102: 335-341.

Khattak, A. M., Pearson, S., 1997. The effect of light quality and temperature on the growth and development of chrysanthemum cv. Bright Golden Anne and Snowdon. Acta Hortic. 435: 113-121.

K ing R ., 2006. Light- regulated plant growth and flowering; from photoreceptors to genes, hormones and signals. Acta Hort. 711:227-233.

Li S., Rajapakse N.C., Young R.E., Oi R., 2000. Growth responses of chrysanthemum and bell pepper transplants to photoselective plastic films. Sci. Hortic. 84: 215-225.

Maki, S.L., Rajapakse, S., Ballard, R.E., Rajapakse, N.C., 2002. Role of gibberellins in chrysanthemum growth under far red light-deficient greenhouse environments. J. Amer. Soc. Hortic. Sci. 127: 639-643.

Mc Mahon M.J., Kelly J.W., 1995. Anatomy and pigments of chrysanthemum leaves developed under spectrally selective filters. Sci. Hort. 64(3): 203-209.

Mc Mahon M.J., Kelly J.W., 1999. $\mathrm{CuSO}_{4}$ filters influence flowering of chrysanthemum cv. Spears. Sci. Hortic. 70:207-215.

Mc Mahon M.J., Kelly J.W., Decoteau D.R., Young R.E., Pollock R.K., 1991. Growth of Dedranthema $x$ grandiflora /Ramat./ Kitamura under various spectral filters. J. Am. Soc. Hort. Sci. 116(6):950-954.

Moe R., Heins R.D., 1990. Control of plant morphogenesis and flowering by light quality and temperature. Acta Hort. 272: 81-90.

Nowak J., Rudnicki R.M., 1990. Postharvest handling and storage of cut flowers, florist greens, and potted plants. Timber Press Inc. Portland, Oregon

Oyaert, E., Volckaert, E., Debergh, P. C., 1999. Growth of chrysanthemum under coloured plastic films with different light qualities and quantities. Scientia Hort. 79: 195-205

Rajapakse N.C., Kelly J.W., 1992. Regulation of chrysanthemum growth by spectral filtres. J. Amer. Soc. Hort. Sci. 117(3): 481-485 
Rajapakse N.C., Mc Mahon M.J., Kelly J.W., 1993. End of day far-red light reverses height reduction of chrysanthemum induced by $\mathrm{CuSO}_{4}$ spectral filters. Sci. Hortic. 53: 249-259.

Rajapakse N.C., Kelly J.W., 1995. Spectral filters and growing season influence growth and carbohydrate status of chrysanthemum. J. Amer. Soc. Hort. Sci. 120(1): 78-83.

Shimizu H., Ma Z., Tazawa S., Douzono M., Runkle E.S., Heins R.D., 2006. Blue light inhibits stem elongation of chrysanthemum. Acta Hort. 711: 363-367.

Zalewska M., Woźny A., Piszczek P., 2002. Effect of blue light on the flowering of Dendranthema grandiflora Tzvelev Sombrero group (in Polish). Zesz. Prob. Post. Nauk Roln.483: 305-310.

\section{Wpływ barwy światła na otwieranie pąków kwiatostanowych i trwałość pozbiorczą chryzantem Chrysanthemum $x$ grandiflorum (Ramat.) Kitam uprawianych w doniczkach}

\section{Streszczenie}

Doniczkową, drobnokwiatową odmianę chryzantemy wielkokwiatowej (Chrysanthemum $\mathrm{x}$ grandiflorum / Ramat./Kitam.) 'Leticia Time Yellow' uprawiano i przechowywano $\mathrm{w}$ pokoju wzrostowym pod lampami fluorescencyjnymi typu TLD-36W emitującymi światło o barwie białej, niebieskiej, zielonej, żółtej i czerwonej. Natężenie napromienienia kwantowego (PPFD) wynosiło $30 \mu \mathrm{mol} \times \mathrm{m}^{-2} \times \mathrm{s}^{-1}$. Wykazano istotny wpływ barwy światła na otwieranie się zamkniętych pąków kwiatostanowych oraz trwałość pozbiorczą kwitnących roślin. Pod świattem o barwie niebieskiej (400-580 nm) pąki kwiatostanowe otwierały się i wybarwiały najwcześniej. Liczba rozwiniętych koszyczków kwiatowych była najwyższa pod lampami o barwie niebieskiej i białej. Koszyczki kwiatowe rozwinięte w świetle niebieskim były większe od koszyczków kwiatowych rozwiniętych w świetle białym i zielonym. W świetle czerwonym (600-700 nm) rośliny rozkwitały najpóźniej i tworzyły najmniejsze koszyczki kwiatowe. Trwałość pozbiorczą zachowały najdłużej rośliny pod lampami o świetle niebieskim, białym i zielonym, pod lampami o świetle czerwonym i żółtym przekwitały najszybciej. 